Artikel Penelitian

\title{
Gambaran Glukosa Darah pada Lansia di Panti Sosial Tresna Werdha Sabai Nan Aluih Sicincin
}

Hayyumahdania Reswan ${ }^{1}$, Yustini Alioes ${ }^{2}$, Rauza Sukma Rita ${ }^{2}$

\begin{abstract}
Abstrak
Angka harapan hidup yang meningkat menandakan terjadinya peningkatan jumlah penduduk Lanjut Usia (Lansia) sehingga terjadi peningkatan permasalahan kesehatan pada lansia karena adanya proses menua yang menyebabkan banyak perubahan pada tubuh lansia. Salah satu perubahan pada tubuh lansia yaitu sistem pengaturan glukosa darah sehingga mengakibatkan peningkatan glukosa darah lebih dari normal. Tujuan penelitian ini adalah untuk mengetahui gambaran kadar glukosa darah pada lansia di Panti Sosial Tresna Werdha (PSTW) Sabai Nan Aluih Sicincin. Penelitian ini merupakan studi deskriptif yang dilaksanakan di PSTW Sabai Nan Aluih Sicincin pada Bulan Agustus 2015 - Februari 2016. Penelitian ini menggunakan data primer dengan mengambil sampel darah jari pada responden yang kemudian diukur dengan Glukometer Easy Touch $®$. Teknik sampling yang digunakan adalah total sampling dengan jumlah sampel yang memenuhi kriteria inklusi adalah 27 orang. Data diolah untuk menghasilkan distribusi dan persentase. Hasil penelitian didapatkan $85,19 \%$ lansia memiliki glukosa darah normal. Berdasarkan usia, lansia usia 60-74 tahun yang memiliki glukosa darah normal yaitu 83,33\% dan lansia berusia 75-70 tahun yang memiliki kadar glukosa darah normal yaitu $86,67 \%$. Berdasarkan jenis kelamin, lansia pria yang memiliki kadar glukosa darah normal sekitar $84,21 \%$ dan lansia wanita yang memiliki kadar glukosa darah normal sekitar $87,50 \%$. Disimpulkan bahwa lebih dari separuh lansia di PSTW Sabai Nan Aluih
\end{abstract}

Kata kunci: lansia, glukosa darah, jenis kelamin, usia

\begin{abstract}
The increasing of life expectancy indicate the increasing of elderly. The increasing of elderly will increase health problem for elderly, because there are many processes to grow old that reflect many changes at elderly's body. One of the changes in elderly's body is blood glucose regulation system which affects an increase in blood glucose. The objective of this study was to know the description of blood glucose in elderly at Panti Social Tresna Werdha (PSTW) Sabai Nan Aluih Sicincin. The study was a descriptive study. This study implemented in PSTW Sabai Nan Aluih Sicincin on August 2015 - February 2016. This study was using a primer data by taking a finger blood sample of respondents, then examined by glucometer Easy Touch ${ }^{\circledR}$. Sampling techniques used are a total of sampling with total of samples that fulfilled criteria were 27 respondents. The data were processed in table to generate frequency and pecentages distribution. The result showed about $85,19 \%$ of elderly had normal blood glucose. Based on age, elderly who were 60-74 years old had normal blood glucose about 83,33\% and elderly who were 75-80 years old had normal blood glucose about $86,87 \%$. Furthermore, based on gender, male elderly had normal blood glucose about $84,21 \%$ and female elderly had normal blood glucose about $87,50 \%$. The conclusion is more than half of elderly at PSTW Sabai Nan Aluih Sicincin have normal blood glucose.
\end{abstract}

Keywords: elderly, blood glucose, gender, age

Affiliasi penulis: 1. Prodi Profesi Dokter FK Unand (Fakultas Kedokteran Universitas Andalas Padang), 2. Bagian Biokimia FK Unand.
Korespondensl: Hayyumahdania Reswan, Email: Hayyu.mahdania@yahoo.com Telp: 0823-7518-4457 


\section{PENDAHULUAN}

Keberhasilan pembangunan di berbagai bidang terutama bidang kesehatan menyebabkan terjadinya peningkatan Usia Harapan Hidup (UHH) penduduk ${ }^{1}$. Usia harapan hidup dunia adalah 71 tahun, berkisar sekitar 62 tahun pada negara berkembang dan 79 tahun pada negara maju. ${ }^{1}$

Harapan hidup di Indonesia dari tahun 1995 sampai tahun 2015 meningkat dari usia 66 tahun menjadi 70,1 tahun. $^{2}$ Angka harapan hidup yang meningkat menandakan terjadinya peningkatan jumlah penduduk lanjut usia (Lansia) yaitu penduduk berusia diatas 60 tahun. $^{3}$

Peningkatan jumlah penduduk lanjut usia dunia tahun 2010 mencapai 524 juta atau sekitar delapan persen dari populasi dunia sedangkan pada tahun 2050 diperkirakan akan meningkat menjadi tiga kali lipat yaitu sekitar 1,5 miliar atau setara dengan 16 persen populasi dunia. ${ }^{4}$

Perkembangan proporsi penduduk lansia di Indonesia mengalami peningkatan dari tahun 1980 sampai tahun 2020 dimana tahun 1980 sekitar 5,45\%; tahun 2010 sekitar 9,77\%; dan diperkirakan pada tahun 2020 meningkat sekitar 11,34\%. Sejak tahun 2000, presentasi penduduk lansia di Indonesia sudah melebihi $7 \%$ sehingga Indonesia mulai masuk dalam kelompok negara berstruktur tua. ${ }^{5}$

Peningkatan jumlah penduduk lanjut usia akan meningkatkan permasalahan kesehatan pada lansia. ${ }^{6}$ Permasalahan kesehatan ini terjadi karena adanya proses menua yang menyebabkan banyak perubahan pada tubuh lansia seperti perubahan psikologis, sosial dan penurunan fungsional tubuh. ${ }^{7}$ Akibat penurunan kapasitas fungsional ini lansia umumnya tidak berespons terhadap berbagai rangsangan seefektif yang dapat dilakukan pada orang yang lebih muda. Penurunan kapasitas untuk merespon rangsangan menyebabkan lansia sulit untuk memelihara kestabilan status fisikawi dan kimiawi tubuh atau memelihara homeostasis tubuh. Gangguan terhadap homeostasis ini menyebabkan disfungsi berbagai sistem organ dan meningkatkan kerentanan terhadap berbagai penyakit. $^{8}$ Salah satu homeostasis yang terganggu yaitu sistem pengaturan kadar glukosa darah.
Gangguan pengaturan glukosa darah pada lansia meliputi tiga hal yaitu resistensi insulin, hilangnya pelepasan insulin fase pertama, dan peningkatan kadar glukosa darah postprandial, diantara ketiga gangguan tersebut yang paling berperan adalah resistensi insulin. Resistensi insulin tersebut dapat disebabkan oleh perubahan komposisi lemak tubuh lansia berupa meningkatnya komposisi lemak dari $14 \%$ menjadi $30 \%$ (masa otot lebih sedikit sedangkan jaringan lemak lebih banyak), menurunnya aktivitas fisik sehingga terjadi penurunan reseptor insulin, perubahan pola makan lebih banyak makan karbohidrat, dan perubahan neurohormonal. $^{9}$

Terganggunya sistem pengaturan glukosa darah mengakibatkan peningkatan glukosa darah lebih dari normal. Glukosa darah meningkat seiring dengan bertambahnya usia. ${ }^{9}$ Seiring dengan proses penuaan semakin banyak lansia yang berisiko terhadap terjadinya Diabetes Melitus. Diabetes Melitus pada lansia umunya bersifat asimptomatik, walaupun ada gejala seringkali berupa gejala yang tidak khas seperti kelemahan, letargi, perubahan tingkah laku, menurunnya status kognitif atau kemampuan fungsional. Hal tersebut yang menyebabkan diagnosis Diabetes melitus pada lansia agak terlambat. ${ }^{9}$

Kondisi fisik dan atau mental lansia yang tidak memungkinkan lagi untuk melakukan aktivitas fisik dan berperan dalam pembangunan nasional butuh perhatian khusus dari pemerintah dan masyarakat. Pemerintah Indonesia mengadakan pelayanan bagi lansia, salah satunya yaitu Panti Werda (Sasana Tresna Werda). ${ }^{10}$

Panti Sosial Tresna Werdha (PSTW) Sabai Nan Aluih Sicincin adalah panti terbesar di Sumatera Barat dengan jumlah lansia terbanyak. Hasil studi penelitian awal pada Juni 2015 didapatkan jumlah lansia pada PSTW Sabai Nan Aluih adalah 110 orang yang dibagi menjadi 14 wisma. Usia lansia pada PSTW ini berkisar dari $61-101$ tahun dengan jumlah lansia laki-laki 70 orang dan perempuan 40 orang.

Berdasarkan uraian latar belakang, maka peneliti merasa perlu untuk melakukan penelitian tentang gambaran glukosa darah pada lansia di Panti Tresna Werdha Sabai Nan Aluih Sicincin. 


\section{METODE}

Penelitian ini merupakan studi deskriptif untuk mengetahui kadar glukosa darah pada lansia di Panti Sosial Tresna Werdha Sabai Nan Aluih Sicincin. Penelitian dilaksanakan di Panti Sosial Tresna Werdha Sabai Nan Aluih Sicincin pada bulan Agustus 2015 Fabruari 2016. Populasi dari penelitian ini adalah seluruh lansia yang menghuni panti sosial tresna werdha "Sabai Nan Aluih" Sicincin pada tahun 2015 berjumlah 110 orang lansia. Sampel pada penelitian ini adalah semua lansia yang menghuni panti sosial tresna werdha "Sabai Nan Aluih" Sicincin pada tahun 2015. Sampel penelitian didapat secara total sampling yang memenuhi kriteria inklusi.

Klasifikasi variable terdiri dari: usia, jenis kelamin, dan kadar glukosa darah. Instrumen yang digunakan dalam penelitian ini adalah glukometer Easy Touch ${ }^{\circledR}$, lanset, kapas alkohol, form identitas pasien, informed consent, form pemeriksaan glukosa darah. Pengambilan data menggunakan metode total sampling dimana semua subjek yang memenuhi kriteria akan dimasukkan ke dalam penelitian. Data diolah secara manual dari responden yang telah diukur glukosa darahnya dan dimasukkan ke dalam tabel. Data yang dicatat: umur, jenis kelamin, kadar glukosa darah kapiler. Prosedur selanjutnya dihitung frekuensi penduduk usia lanjut di Panti Sosial Tresna Werda yang memiliki glukosa normal dan lebih dari kadar normal, lalu disajikan dalam bentuk tabel.

\section{HASIL}

Penelitian ini dilakukan pada bulan Agustus 2015 - Februari 2016 di Panti Sosial Tresna Werdha Sabai Nan Aluih Sicincin. Hasil penelitian tersebut didapatkan 27 orang yang memenuhi kriteria inklusi.

Tabel 1. Distribusi frekuensi berdasarkan umur

\begin{tabular}{lcc}
\hline \multicolumn{1}{c}{ Umur } & Frekuensi & Persentase \\
\hline $60-74$ tahun & 12 & $44,44 \%$ \\
$75-90$ tahun & 15 & $55,56 \%$ \\
$\geq 90$ tahun & 0 & $0 \%$ \\
\hline Jumlah & 27 & $100 \%$ \\
\hline
\end{tabular}

Berdasarkan Tabel 1 diketahui bahwa frekuensi usia lanjut terbanyak berusia 75-90 tahun sebanyak 15 orang $(55,56 \%)$.

Tabel 2. Distribusi frekuensi berdasarkan jenis kelamin

\begin{tabular}{lcc}
\hline Jenis kelamin & Frekuensi & Persentase \\
\hline Pria & 19 & $70,37 \%$ \\
wanita & 8 & $29,63 \%$ \\
\hline Jumlah & 27 & $100 \%$ \\
\hline
\end{tabular}

Berdasarkan Tabel 2 diketahui frekuensi jenis kelamin lansia terbanyak adalah pria sebanyak 19 orang $(70,37 \%)$.

Tabel 3. Distribusi frekuensi kadar glukosa darah

\begin{tabular}{ccc}
\hline $\begin{array}{c}\text { Kadar glukosa } \\
\text { darah }\end{array}$ & frekuensi & Persentase \\
\hline $\begin{array}{c}\text { Normal }(<140 \\
\mathrm{mg} / \mathrm{dl})\end{array}$ & 23 & $85,19 \%$ \\
$\begin{array}{c}\text { Tinggi }(\geq 140 \\
\mathrm{mg} / \mathrm{dl})\end{array}$ & 4 & $14,81 \%$ \\
\hline Total & 27 & $100 \%$ \\
\hline
\end{tabular}

Berdasarkan Tabel 3 diketahui kadar glukosa darah normal sebanyak 23 orang $(85,19 \%)$.

Tabel 4. Gambaran glukosa darah lansia berdasarkan umur

\begin{tabular}{lcccc}
\hline \multicolumn{1}{c}{$\begin{array}{c}\text { Glukosa } \\
\text { Darah }\end{array}$} & \multicolumn{2}{c}{$\mathbf{6 0 - 7 4}$ tahun } & \multicolumn{2}{c}{$\mathbf{7 5 - 9 0}$ tahun } \\
\cline { 2 - 5 } & $\mathbf{f}$ & $\mathbf{\%}$ & $\mathbf{f}$ & $\mathbf{\%}$ \\
\hline $\begin{array}{l}\text { Normal } \\
(<140 \mathrm{mg} / \mathrm{dl})\end{array}$ & 10 & $83,33 \%$ & 13 & $86,67 \%$ \\
$\begin{array}{l}\text { Tinggi }(\geq \\
140 \mathrm{mg} / \mathrm{dl})\end{array}$ & 2 & $16,67 \%$ & 2 & $13,33 \%$ \\
\hline \multicolumn{1}{c}{ Total } & 12 & $100 \%$ & 15 & $100 \%$ \\
\hline
\end{tabular}

Berdasarkan Tabel 4 diketahui frekuensi lansia yang memiliki kadar glukosa darah normal terbanyak adalah pada usia 75-90 tahun yaitu 13 orang $(86,67 \%)$. 
Tabel 5. Gambaran glukosa darah lansia berdasarkan jenis kelamin

\begin{tabular}{ccccc}
\hline \multirow{2}{*}{ Glukosa Darah } & \multicolumn{2}{c}{ Pria } & \multicolumn{2}{c}{ Wanita } \\
\cline { 2 - 5 } & $\mathbf{f}$ & $\%$ & $\mathbf{f}$ & $\%$ \\
\hline $\begin{array}{c}\text { Normal } \\
(<140 \mathrm{mg} / \mathrm{dl})\end{array}$ & 16 & $84,21 \%$ & 7 & $87,50 \%$ \\
$\begin{array}{c}\text { Tinggi } \\
(\geq 140 \mathrm{mg} / \mathrm{dl})\end{array}$ & 3 & $15,79 \%$ & 1 & $12,50 \%$ \\
\hline Total & 19 & $100 \%$ & 8 & $100 \%$ \\
\hline
\end{tabular}

Berdasarkan Tabel 5 frekuensi lansia yang memiliki kadar glukosa darah normal terbanyak adalah lansia wanita yaitu 7 orang $(87,50 \%)$.

\section{PEMBAHASAN}

Penelitian ini dilakukan untuk melihat gambaran glukosa darah pada lansia di Panti Sosial Tresna Werdha Sabai Nan Aluih Sicincin. Data didapatkan dengan pengukuran langsung glukosa darah pada Desember 2015 pada seluruh lansia yang menghuni Panti Sosial Tresna Werdha Sabai Nan Aluih Sicincin. Jumlah lansia yang menghuni panti tersebut sekitar 110 orang dan 27 orang lansia yang memenuhi kriteria inklusi. Subyek penelitian dikelompokkan berdasarkan umur dan jenis kelamin.

Subyek penelitian dikelompokkan berdasarkan umur menjadi tiga kelompok yaitu : 60-74 tahun, 75-90 tahun, dan $>90$ tahun. Jumlah lansia yang berusia $60-$ 74 tahun adalah 12 orang (44,44\%), kelompok $75-90$ tahun adalah 15 orang $(55,56 \%)$, dan kelompok usia $>90$ tahun tidak ada yang memenuhi kriteria inklusi sehingga persentase kelompok usia $>90$ tahun adalah $0 \%$. Subyek penelitian berdasarkan jenis kelamin didapatkan 19 orang lansia laki-laki atau sekitar $70,37 \%$ dan 8 orang lansia wanita atau sekitar $29,63 \%$.

Pada penelitian ini ditemukan lansia yang memenuhi kriteria diabetes sebanyak 4 orang $(14,81 \%)$ dan lansia yang memiliki glukosa normal sebanyak 23 orang (85,19\%). Penelitian ini sesuai dengan penelitian Rosyada dan Trihandini tahun 2013 yang dilakukan pada poliklinik lansia Puskesmas Kecamatan Jatinegara ditemukan lansia yang masuk kedalam kriteria diabetes melitus sekitar 35,5 \%. ${ }^{11}$ Hal ini disebabkan karena sekitar $50 \%$ lansia mengalami gangguan pada metabolisme glukosa sehingga lansia cenderung mengalami peningkatan glukosa darah. ${ }^{9}$
Berbeda dengan penelitian Sibarani tahun 2010, tidak ditemukan lansia yang memenuhi kriteria diabates. Semua lansia yang menjadi responden yaitu 37 orang memiliki glukosa darah kurang dari 140 $\mathrm{mg} / \mathrm{dl}$ dimana rata-rata glukosa darah dari 37 lansia tersebut adalah 109,63 mg/dl yang menunjukkan bahwa glukosa darah lansia tergolong normal. ${ }^{12}$ Sama seperti penelitian Sibarani, penelitian dari Fakhrudin tahun 2013 didapatkan bahwa dari 20 orang lansia yang menjadi subjek tidak ada yang mengalami peningkatan glukosa darah. Pada penelitian tersebut didapatkan rata-rata kadar glukosa darah lansia $<140$ $\mathrm{mg} / \mathrm{dl}$ dengan rata-rata $138,7 \mathrm{mg} / \mathrm{dl}^{13}$

Umur merupakan salah satu faktor mandiri terhadap peningkatan glukosa darah, terlihat dari prevalensi diabetes yang meningkat bersama dengan pertambahan umur. Umumnya diabetes pada dewasa hampir $90 \%$ termasuk diabetes tipe 2, dari jumlah tersebut $50 \%$ adalah pasien yang berusia diatas 60 tahun. ${ }^{14}$ Peningkatan kadar glukosa darah disebabkan karena terganggunya homeostasis pengaturan glukosa darah. Gangguan pengaturan glukosa darah pada lansia meliputi tiga hal yaitu resistensi insulin, hilangnya pelepasan insulin fase pertama, dan peningkatan kadar glukosa darah postprandial, diantara ketiga gangguan tersebut yang paling berperan adalah resistensi insulin. Resistensi insulin tersebut dapat disebabkan oleh perubahan komposisi lemak tubuh lansia berupa meningkatnya komposisi lemak dari $14 \%$ menjadi $30 \%$ (masa otot lebih sedikit sedangkan jaringan lemak lebih banyak), menurunnya aktivitas fisik sehingga terjadi penurunan reseptor insulin, perubahan pola makan lebih banyak makan karbohidrat, dan perubahan neurohormonal. ${ }^{14}$ Pada penelitian ini diketahui frekuensi usia 60-74 tahun dengan glukosa darah normal sesuai dengan kriteria WHO 1985 sebanyak 10 orang (83,33\%) sedangkan usia $75-90$ tahun sebanyak 13 orang $(86,67 \%)$, dan lansia yang termasuk dalam kriteria diabetes pada usia 60-74 tahun dan 75-90 tahun masing-masing hanya 2 orang, 16,67 \% pada usia 60 - 74 tahun dan $13,33 \%$ pada usia $75-90$ tahun. Penelitian ini sesuai dengan penelitian pada penelitian Rosyada dan Trihandini tahun 2013 yang dilakukan pada poli lansia puskesmas Kecamatan Jatinegara lansia yang masuk kriteria diabetes melitus berdasarkan usia, yaitu usia 60-69 tahun sekitar 29,3\% dan usia $\geq 70$ tahun sekitar 
$20,8 \%,{ }^{11}$ sedangkan pada penelitian Sibarani tahun 2010 tidak ditemukan lansia yang masuk kedalam kriteria diabetes menurut WHO 1985. Pada penelitian tersebut menggunakan kriteria usia yang berbeda, dimana pembagian kriteria usia menjadi tiga yaitu 6074 tahun, 75-84 tahun dan $\geq 85$ tahun. Usia $60-74$ tahun yang memiliki glukosa darah normal $(<140$ $\mathrm{mg} / \mathrm{dl}$ ) ada sekitar 28 lansia (75,7\%), usia 75-84 tahun adalah 6 lansia $(16,2 \%)$ dan usia $\geq 85$ tahun adalah 3 lansia $(8,1 \%) .{ }^{12}$ Semua lansia yang menjadi responden dari Sibarani memiliki glukosa darah dengan rata-rata 109, $63 \mathrm{mg} / \mathrm{dl}$. Pada penelitian Sibarani tidak ditemukan peningkatan kadar glukosa darah pada lansia. Terlihat dari penelitian tersebut selain faktor usia terdapat faktor lain yang bisa mempengaruhi kadar glukosa darah pada lansia seperti asupan makanan, aktivitas fisik, obat-obatan, pengetahuan, pendidikan dan keterpaparan terhadap sumber informasi. ${ }^{15}$

Distribusi frekuensi kadar glukosa darah pada lansia berdasarkan jenis kelamin didapatkan lansia pria dengan glukosa darah normal sebanyak 16 orang $(84,21 \%)$ sedangkan lansia wanita sebanyak 7 orang atau $(87,50 \%)$. Terlihat dari presentase glukosa darah normal antara lansia pria dan wanita tidak terlalu banyak perbedaan. Penelitian ini sesuai dengan penelitian Sibarani tahun 2010 seluruh lansia pria dan wanita memiliki kadar glukosa darah normal dengan rata-rata glukosa darah pada wanita yaitu 109,45 $\mathrm{mg} / \mathrm{dl}$ dan lansia pria $114 \mathrm{mg} / \mathrm{dl}$. Dari kedua penelitian ini jenis kelamin tidak mempengaruhi kadar glukosa darah, ${ }^{12}$ sedangkan berdasarkan Fakhruddin tahun 2013 jenis kelamin mempengaruhi kadar glukosa darah karena perubahan persentase komposisi lemak tubuh pada lansia wanita lebih tinggi daripada lansia pria yang dapat menurunkan sensitifitas insulin. ${ }^{13}$ Perubahan komposisi lemak pada wanita yang telah menopouse terjadi karena penurunan kadar hormon estrogen dan progesteron. ${ }^{10}$ Apabila hormon estrogen dan progesteron menurun penggunaan lemak pada lansia wanita menjadi berkurang. ${ }^{13}$

\section{SIMPULAN}

Mayoritas lansia memiliki kadar glukosa darah normal yaitu 23 orang $(85,19 \%)$.
Berdasarkan usia, lansia usia 60-74 tahun memiliki glukosa darah normal yaitu 10 orang $(83,33 \%)$ dan lansia berusia $75-70$ tahun yang memiliki kadar glukosa darah normal adalah 13 orang (86,67\%).

Berdasarkan jenis kelamin, lansia pria yang memiliki kadar glukosa darah normal adalah 16 orang $(84,21 \%)$ dan lansia wanita yang memiliki kadar glukosa darah normal 7 orang $(87,50 \%)$.

\section{UCAPAN TERIMAKASIH}

Terimakasih kepada semua pihak yang sudah membantu dan memberikan motivasi penulis dalam penelitian ini.

\section{DAFTAR PUSTAKA}

1. World Health Organization (WHO). Life expectancy. 2015 (diunduh 20 Juli 2015). Tersedia dari: URL: HYPERLINK http://www.who.int/gho/ mortality burden disease/life tables/situation tren ds text/en/

2. Badan Pusat Statistik. Angka harapan hidup penduduk beberapa negara (tahun) 1995-2015. Badan Pusat Statistik; 2010 (diunduh 20 juli 2015). Tersedia dari: URL: HYPERLINK http://www.bps.go.id/linkTabelStatis/ view/id/1517

3. Badan Pusat Statistik. Statistik penduduk lanjut usia. Jakarta-Indonesia. Badan Pusat Statistik; 2013.

4. World Health Organization (WHO). Global health and aging. 2011 (diunduh 20 juli 2015). Tersedia dari: URL: HYPERLINK http://www.who.int/ageing/ publications/global health.pdf

5. Kementerian Kesehatan RI. Situasi dan analisis lanjut usia. Depkes; 2014 (diunduh 20 Juni 2015). Tersedia dari: URL: HYPERLINK http://www.depkes.go.id/resources/download/pusd atin/infodatin/infodatin-lansia.pdf

6. Nugroho W. Komunikasi dalam keperawatan gerontik. Jakarta: EGC; 2009.

7. Nugroho HA. Perubahan fungsi fisik dan dukungan keluarga dengan respon psikososial pada lansia di Kelurahan Kembangarum Semarang. Jurnal keperawatan. 2007;1(1):45-57. 
8. Setiati S, Kuntjoro H, Arya G R. Proses menua dan implikasi kliniknya. Dalam: Sudoyo AW, Setiyohadi B, Alwi I, K Simadibrata M, Setiadi S, editor (penyunting). Buku ajar ilmu penyakit dalam. Edisi ke-5. Jakarta: Interna Publishing;2009.

9. Kurniawan. Diabetes melitus tipe 2 pada usia lanjut. Majalah Kedokteran Indonesia. 2010;60 (12):576-84.

10. Darmojo B. Buku Ajar geriatri (ilmu kesehatan usia lanjut). Edisi ke-4. Jakarta: Balai Penerbit Fakultas Kedokteran Universitas Indonesia; 2009.

11. Rosyada A,Trihandini I. Determinan komplikasi kronik diabetes melitus pada lanjut usia. Jurnal Kesehatan Masyarakat Nasional. 2013;7(9):395401.

12. Sibarani D. Gambaran kadar glukosa darah lansia puasa dan dua jam sesudah makan di panti jompo Dharma Asih Binjai Sumatera Utara. Medan: Universitas Sumatera Utara; 2010
13. Fakhruddin $H$. Pengaruh senam jantung sehat terhadap kadar glukosa darah pada lansia di panti sosial dan lanjut usia tresna werdha Natar Lampung Selatan. Medical Journal Of Lampung University. 2013 (diunduh 30 Januari 2016). Tersedia dari: URL: HYPERLINK http://juke. kedokteran.unila.ac.id/index.php/majority/article/vie $\underline{w} / 43$

14. Rochmah W. Diabetes melitus pada usia lanjut. Dalam: Sudoyo AW, Setiyohadi B, Alwi I, K Simadibrata M, Setiadi S, editor (penyunting). Buku ajar ilmu penyakit dalam. Edisi ke-5. Jakarta: Interna Publishing;2009.

15. Qurratuaeni. Faktor-faktor yang berhubungan dengan terkendalinya kadar gula darah pada pasien diabetes melitus di rumah sakit umum Pusat Fatmawati. Jakarta. Universitas Islam Negeri Jakarta; 2009. 